\title{
リン酸二水素アンモニゥムと $\boldsymbol{\alpha}$-アルミナ, $\boldsymbol{\gamma}$-アルミナ, 水酸化アルミニウム および金属アルミニウムとの反応生成物とその酸性質*1,*2 \\ (昭和 46 年 8 月 10 日曼理)
}

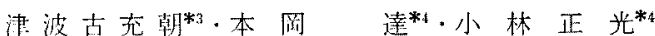

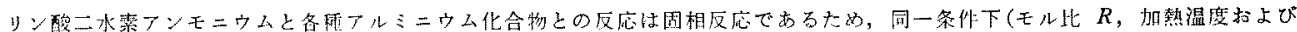

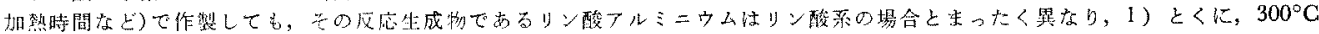

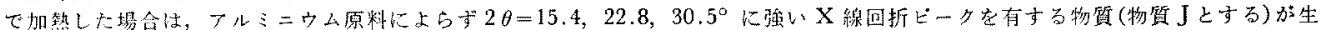

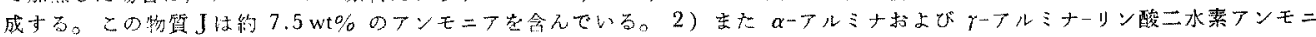

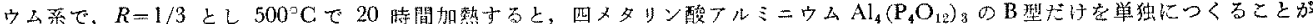

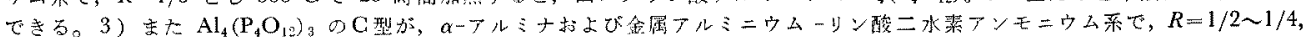

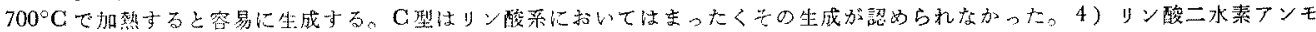
ニウム柔に拉いて, K 物質や $\mathrm{AlPO}_{4}$ (Berlinite 型) はまったく生成しなかった。

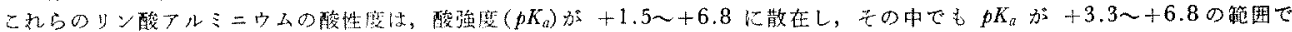

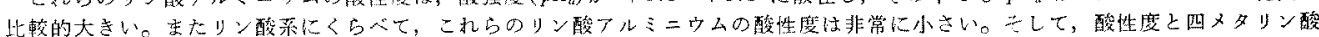

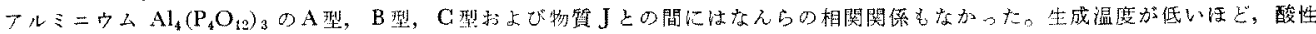

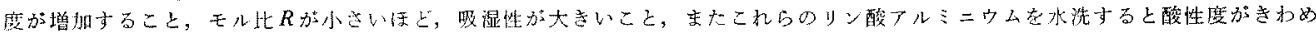
て小さくなることから，とれらのリン酸フルミニウムの酸性発現の主なる要因は，遊能のリン酸によるBrønsted 酸であると考克 られる。
\end{abstract}

\section{1 鍺 言}

リン酸水荸二アンモニウムと硫酸アルミニウム西るいはアルミ ニウムミ゙ウバンとの反応によるリン酸アルミニウムの生成につ いての研究は二三あるが，そのほとんどが溶液反応であるり。

委た日ン酸二水素アンモニウムとアルミニウム化合物との周相 反応により生成するりン酸アルミニウム以関与る研究は少なく，

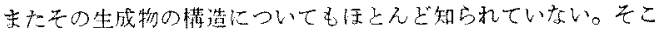
で蒋者らはリン酸アルミニウムの製法拉上びその性筫を研究する ために，前報りに括いてりン原料としてりン酸を用いたが，本研 究ではりン酸二水素アンモニウムを使用し，アルミニウム原料と しては $\alpha$ ーアルミナ, $\gamma$ ーアルミ゙，水酸化アルミニウム(ハイドラ ルジライト型)就よ゙金属アルミニウム老用いて周相反応により リン酸アルミニウムをつくり，それぞれの反応生成物についてX

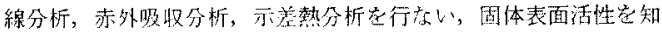
る目的て固体陵性筫調心，二三の知罟を得たのでここに報告す る。

\section{2 実験}

\section{1 試 薬}

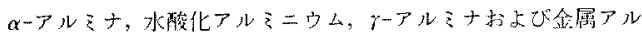

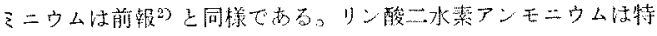

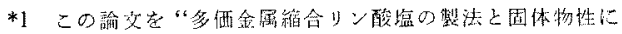

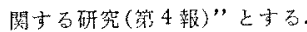

*2 前報(第 3 報)，津波古充朝，本阔 造，小林正光，口化， 92, $1131(1971)$.

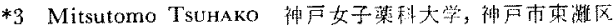
本山阔中野

*4 Itaru Motooka, Masamitsu KoBayasht 神戸大学教

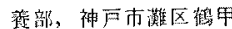

1）小林種雄，突恊，71[11]，201(1963).

2) 前報(第 3 報)，津波古充朝，本阔蓬，小林正光，日化， $92,1131(1971)$
級品 (和光純藻) を用いた。

\section{2 リン酸アルミニゥムの製法}

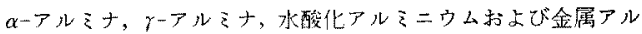
ミ二ウム炤末とり之酸二水素アンモ二ウムとを種々のモル比 $R$ $\left(\mathrm{Al}_{2} \mathrm{O}_{3} / \mathrm{P}_{2} \mathrm{O}_{5}\right)$ で, 力クハンライカイ(㨨找攉演)機で約 20 分間混合 L $300,500,700^{\circ} \mathrm{C}$ の電気灯中で 20 時間加熱した。この上うに

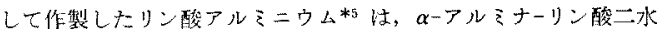
素アンモニウム系の場合は固く，ケーアルミナ，水酸化アルミ゙ウ ム沽よひ金属アルそ二ウムの場合はもるく，さらきらとした固体 が得られる。前報2と同标に，とのりン酸アルミニウムを粗哱後

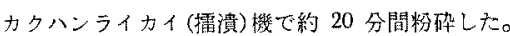

\section{3 実験装鞰および測定法}

水分の測定は京都電子工業株式会社製 Karl Fischer 水分測定

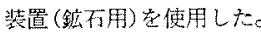

X線分析，示差熱分析および赤外吸収分析は前報ると同様であ

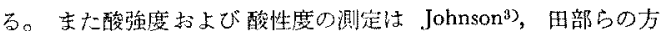
法455によって求めた。

\section{3 実験結果と考察}

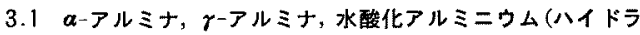
ルジライト型)および 金属アルミニウムとリン酸二水素アンモニ ウムとの反応生成物

$300^{\circ} \mathrm{C}$ て加熱した場合:い鸟机の系についても， $R\left(\mathrm{Al}_{2} \mathrm{O}_{3} / \mathrm{P}_{2} \mathrm{O}_{5}\right)$ $=1 / 0.7 \sim 1 / 4$ の全谼域にわたって图 1 に示すような $2 \theta=15.4$, $22.8,30.5^{\circ}$ に強いX線回折ピークをるつ物質(物質 $\mathrm{J}$ とる)が

*5このようにして作擎したリン酸丁ルミニウムはナンモニ フ艺含えでもる

3) O. Johnson, J. Phys. Chem., 59, 827(1955).

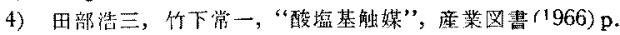
159.

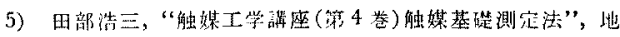
人军领 (1964) p. 161 . 


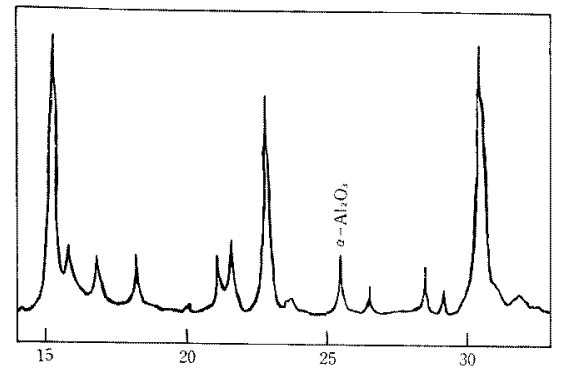

回折筩 $20\left({ }^{\circ}\right) \quad C u K_{\alpha}(40 \mathrm{kV}-7 \mathrm{~mA})$

$R=1 / 1.0, \quad$ 加熱温瑟 $500^{\circ} \mathrm{C}$, 加熱持閶 $20 \mathrm{hr}$

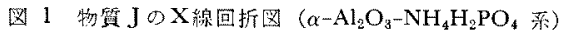

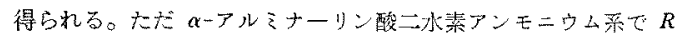

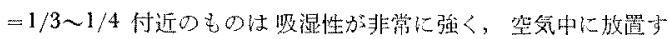

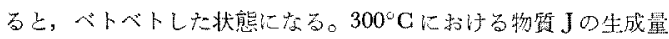
艺線回折强度加与求

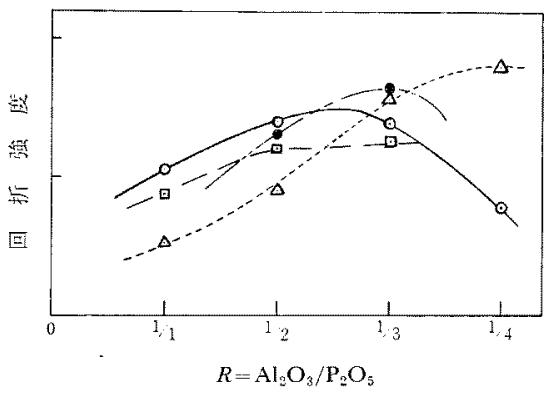

$\odot: \alpha-\mathrm{Al}_{2} \mathrm{O}_{3}-\mathrm{NH}_{4} \mathrm{H}_{2} \mathrm{PO}_{4}$ 䒺

- $\gamma-\mathrm{Al}_{2} \mathrm{O}_{3}-\mathrm{NH}_{4} \mathrm{H}_{2} \mathrm{PO}_{4}$ 皮

$\Delta: \mathrm{Al}(\mathrm{OH})_{3}-\mathrm{NH}_{4} \mathrm{H}_{2} \mathrm{PO}_{4}$ 菜

[.]: $\mathrm{Al}-\mathrm{NH}_{4} \mathrm{H}_{2} \mathrm{PO}_{4}$ 丞

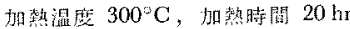

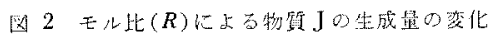

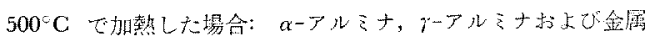

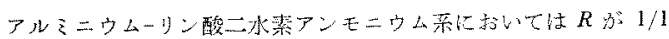

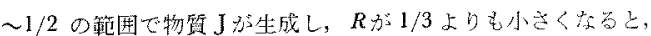

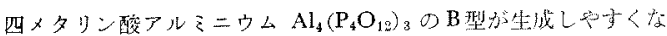

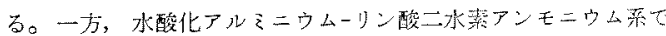

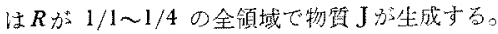

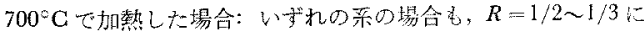

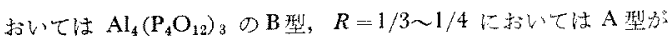

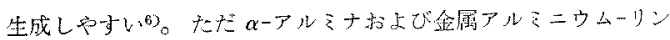

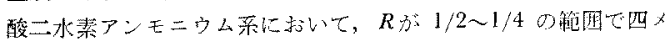

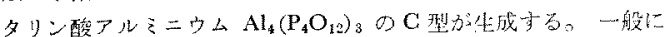

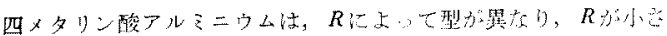

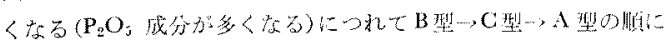
生成しや寸くなる。しかしたいていの場合は，䒘九狆の混合物

6) E. Thilo, I. Grunze, Z. Anorg. Chem., 290, 233 (1957).
として得ら机る。

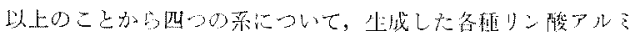

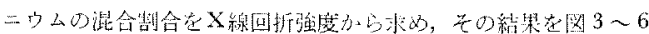

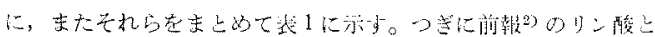

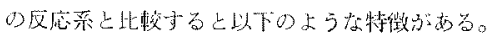

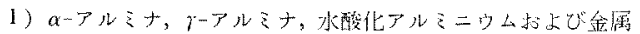

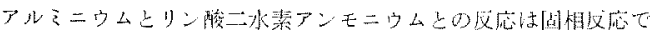

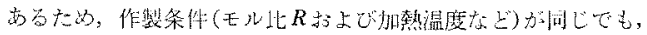

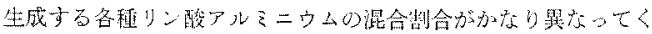
b。

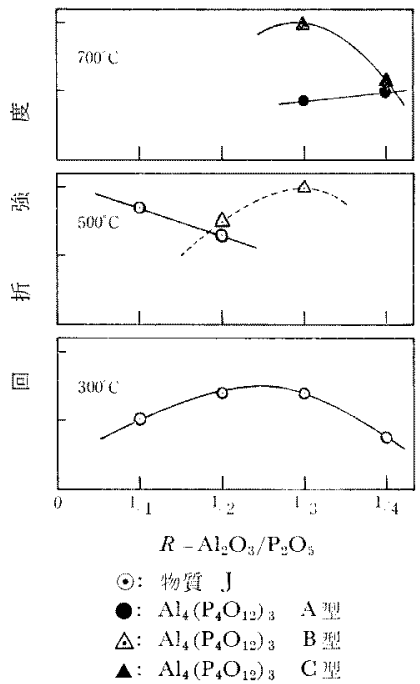

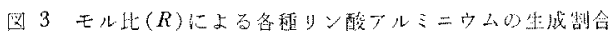
の变化 $\left(\alpha-\mathrm{Al}_{2} \mathrm{O}_{3}-\mathrm{NH}_{4} \mathrm{H}_{2} \mathrm{PO}_{4}\right.$ 烈 $)$

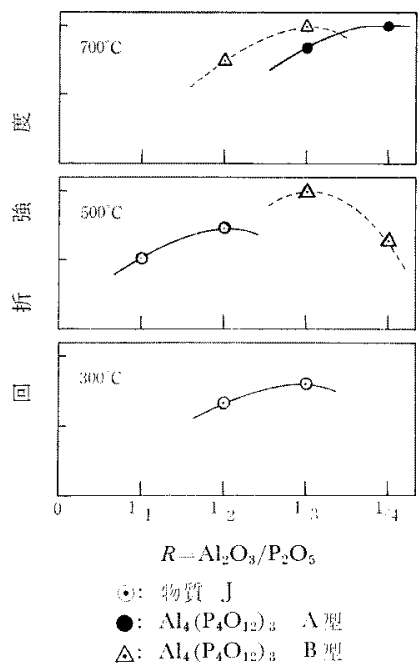

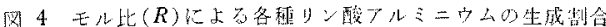
の雍化 $\left(\gamma-\mathrm{Al}_{2} \mathrm{O}_{3}-\mathrm{NH}_{4} \mathrm{H}_{2} \mathrm{PO}_{4}\right.$ 菜 $)$ 


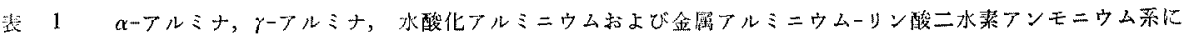
おけるリン酸丁ルミニウムの生成策件と生成物との関係

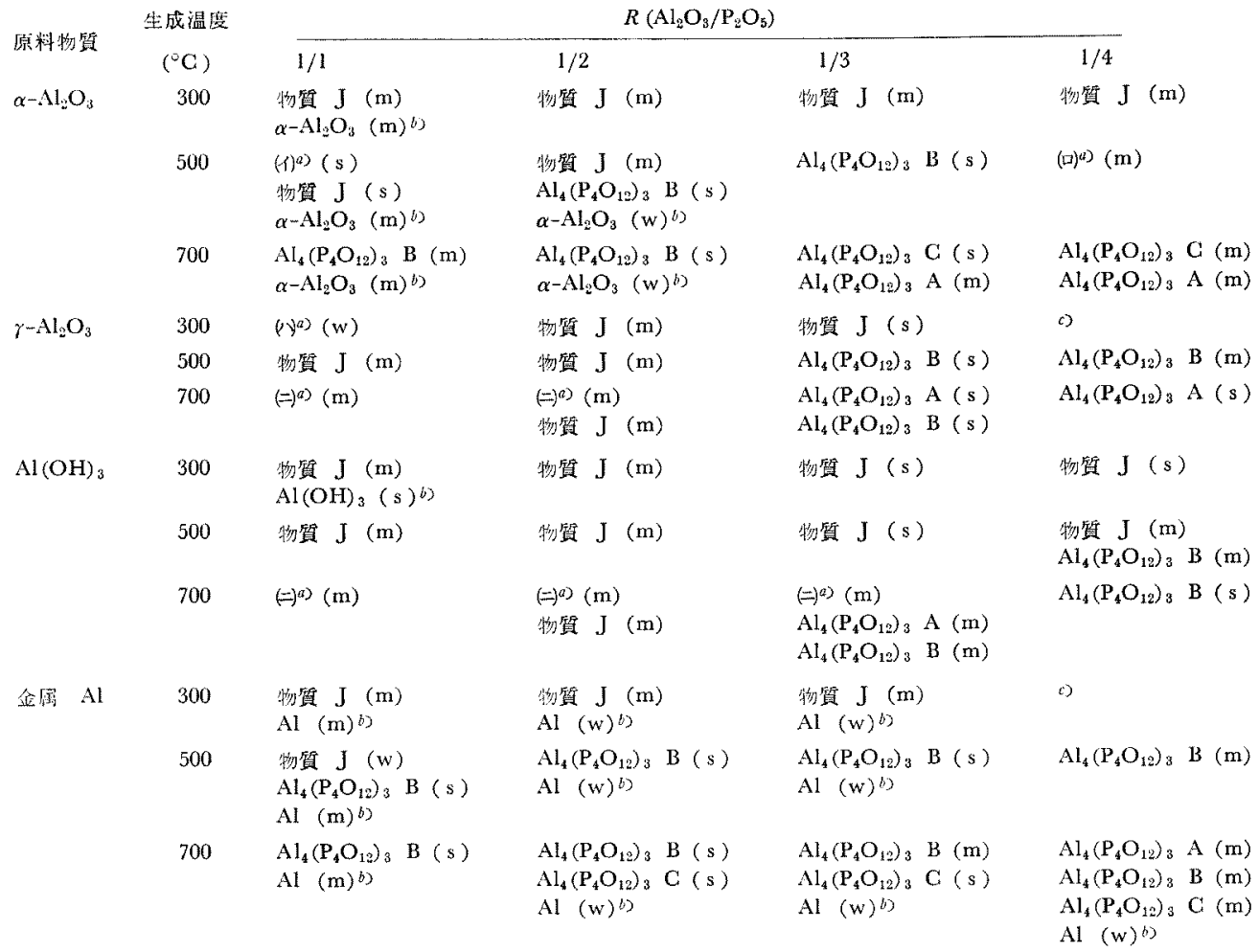

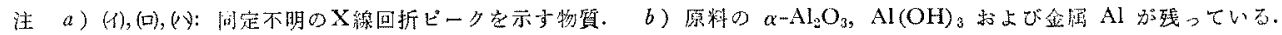
c) 吸湿性方大意く澌定不可能. 回折强留 $\mathrm{s}$ : 強, $\mathrm{m}$ : 中程度, $\mathrm{w}$ : 弱.

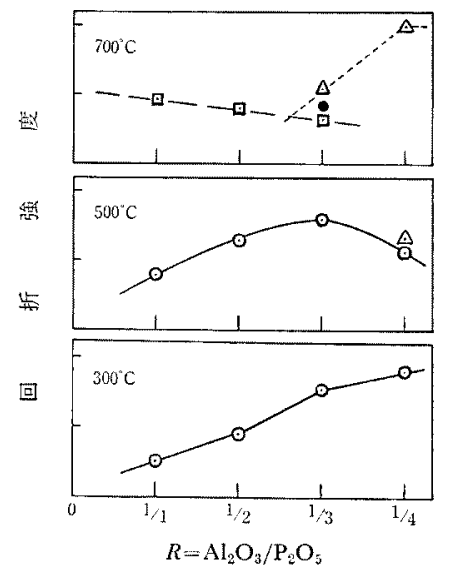

$\odot$ : 物犋 $\mathrm{J}$

- : $\mathrm{Al}_{4}\left(\mathrm{P}_{4} \mathrm{O}_{12}\right)_{3} \quad \mathrm{~A}$ 㑭 $\triangle: \mathrm{Al}_{4}\left(\mathrm{P}_{4} \mathrm{O}_{12}\right)_{3} \quad \mathrm{~B}$ 型 $\quad \square:($

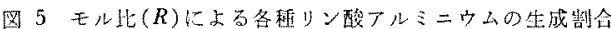
变化 $\left(\mathrm{Al}(\mathrm{OH})_{3}-\mathrm{NH}_{4} \mathrm{H}_{2} \mathrm{PO}_{4}\right.$ 䒺 $)$

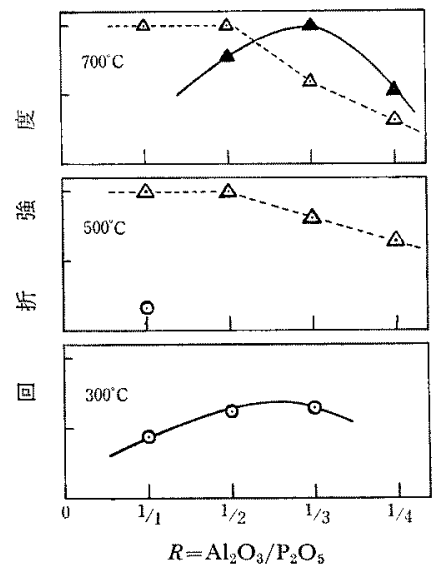

O: 物蟹 I

$\triangle: \mathrm{Al}_{4}\left(\mathrm{P}_{4} \mathrm{O}_{12}\right)_{3} \quad \mathrm{~B}$ 型 $\Delta: \mathrm{Al}_{4}\left(\mathrm{P}_{4} \mathrm{O}_{10}\right)_{3} \quad \mathrm{C}$ 猄

四 6 モル此 $(R)$ による各種リン酸アルミニウムの生成制合 の㴶化 $\left(\mathrm{Al}-\mathrm{NH}_{4} \mathrm{H}_{2} \mathrm{PO}_{4}\right.$ 亲 $)$ 


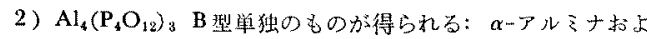
びテーアルミナーリン酸二水素アンモニウム系で， $R=1 / 3 \succeq し$ $500^{\circ} \mathrm{C}$ で 20 時間加熱すると，四メタリン酸アルるニウム $\mathrm{Al}_{4}$.

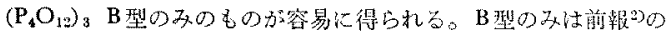
リン酸柔や他の系では得られない。

3) $\mathrm{Al}_{4}\left(\mathrm{P}_{4} \mathrm{O}_{12}\right)_{3} \mathrm{C}$ 型が得られる: $\alpha$ ーアルミナ怙よび金属アル そニウムーリン酸二水素アンモ二ウム系で $R=1 / 2 \sim 1 / 4$, 加熱温 度 $700^{\circ} \mathrm{C}$ て坐成する。C型はリン酸秃化频いては委ったくその 生成唯認められない。

4) 前報のリン酸系飞おいて比较的多く生成した $\mathrm{AlPO}_{4}$ (Berli-

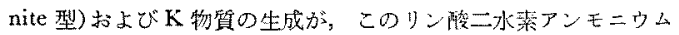
系においてはまったく生成しない。

5) 原料物锤の $\alpha$-アルミナ，水酸化アルミ二ウム技よび金属 アルミニウムがリン酸系にくらべて米反応物として残りやすい。 とくに金属アルミニりムの場合には， $R=1 / 4$ でもアルミニウム の金属色が残っていた。

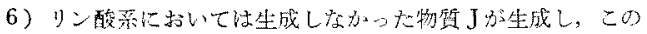

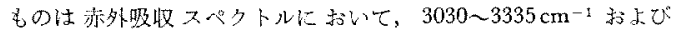

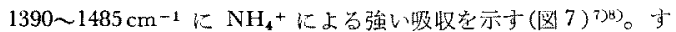
な⿰氵 $300,500^{\circ} \mathrm{C}$ で加熱生成した試料はアンモニアがまだ完全 に揮散せざ，生成したリン酸アルミニウム注 $\mathrm{NH}_{4}+$ を含も化合 物である。その組成洼表 2 に示主上妨りで，約 $7.5 \mathrm{wt} \%$ のア モニアを含むでいる。

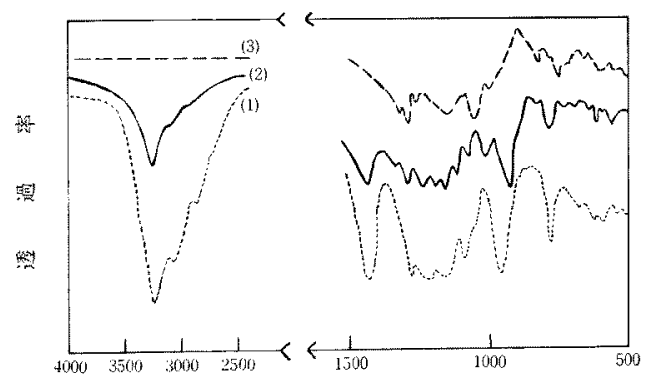

波

(1): $300 \circ \mathrm{C}$ で 20 時間加数

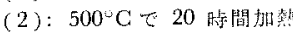

(3)： $700^{\circ} \mathrm{C} て 20$ 時關扔熱

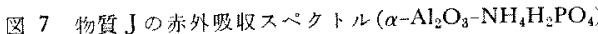

\section{2 酸強度と酸性度}

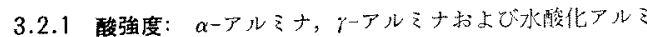
ニウムとリン酸二水棐アンモ二ウムとから作留したりン酸アル

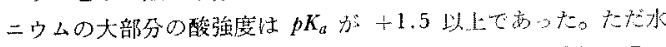

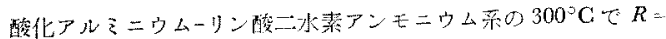

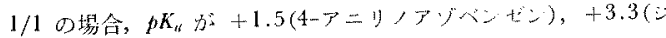

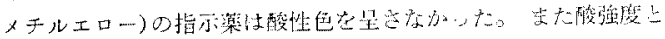

7) M. Grayson, E. J. Griffith, "Topics in phosphorus chemistry Vol. 6", Interscience Publischers(1969) p. 325.

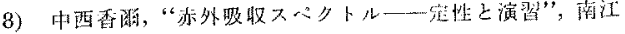
堂 $(1970)$ p. 61

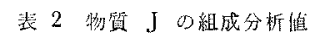

\begin{tabular}{|c|c|c|c|c|}
\hline $\begin{array}{l}\text { 試 料 } \\
\text { No. }\end{array}$ & $\begin{array}{c}\left.\mathrm{P}_{2} \mathrm{O}_{5}\right) \\
(\%)\end{array}$ & $\begin{array}{c}\left.\mathrm{Al}_{2} \mathrm{O}_{3} b\right) \\
(\%)\end{array}$ & $\begin{array}{c}\left.\mathrm{H}_{2} \mathrm{O} \%\right) \\
(\%)\end{array}$ & $\begin{array}{c}\left.\mathrm{NH}_{3} d\right) \\
(\%)\end{array}$ \\
\hline 43 & 62.3 & 16.0 & 10.7 & 7.3 \\
\hline 52 & 62.4 & 16.3 & 10.8 & 7.5 \\
\hline 53 & 62.0 & 17.6 & 9.3 & 7.6 \\
\hline 54 & 61.3 & 17.8 & 7.8 & 7.3 \\
\hline 55 & 61.0 & 18.5 & 8.0 & 7.4 \\
\hline 56 & 62.1 & 14.6 & 10.7 & 7.5 \\
\hline
\end{tabular}

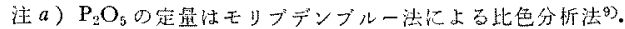

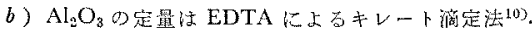

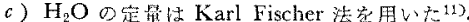

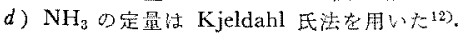

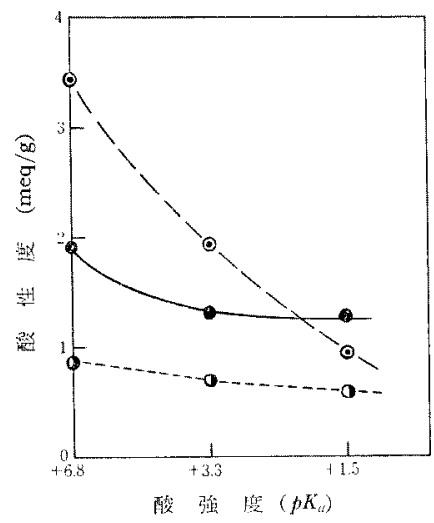

$\odot: a-\mathrm{Al}_{2} \mathrm{O}_{3}-\mathrm{NH}_{4} \mathrm{H}_{2} \mathrm{PO}_{4}$ 集 $\quad \mathrm{R}-1 / 2.9 \quad 300^{\circ} \mathrm{C}$

- : $i-\mathrm{Al}_{2} \mathrm{O}_{3}+\mathrm{NH}_{4} \mathrm{H}_{2} \mathrm{PO}_{4}$ 桨 $\quad R-1 / 3.0 \quad 300 \cdot \mathrm{C}$

(): $\mathrm{Al}(\mathrm{OH})_{3}-\mathrm{NH}_{4} \mathrm{H}_{2} \mathrm{PO}_{4}$ 采 $\quad R=1 / 3.0 \quad 300^{\circ} \mathrm{C}$

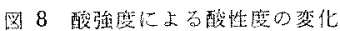

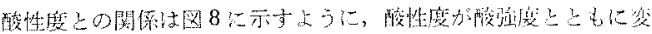

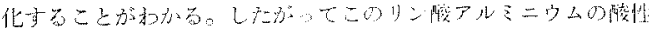

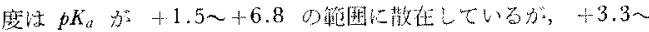

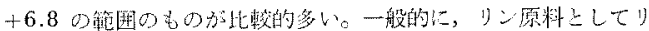

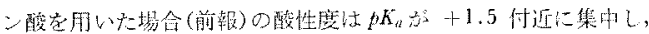

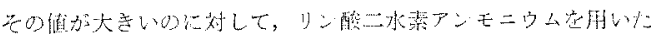

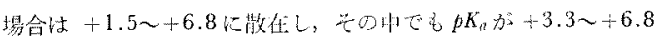

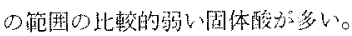

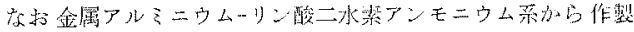
したりン酸アルそニウムはRの大小に放和らず，アルミニウム

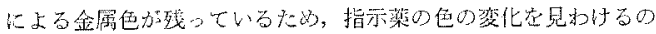
か国蜼で，酸强度上酸性度が湘定できなった。

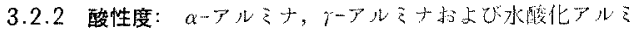
ニウムーリン酸二水素アンモ二ウム䒺について，その結果の一例

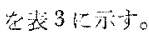

一连の生成条件下て作製したリン耎アルミニウムについては,

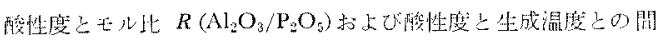

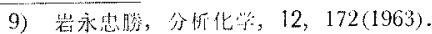

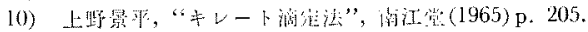

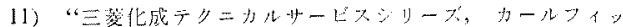

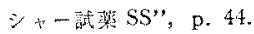

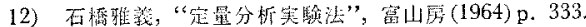




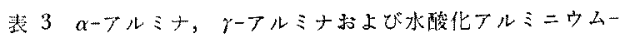

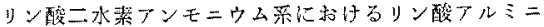

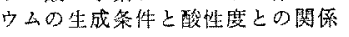

\begin{tabular}{|c|c|c|c|c|c|c|}
\hline \multirow{2}{*}{$\begin{array}{l}\text { 陚料 } \\
\text { No. }\end{array}$} & \multirow{2}{*}{$\frac{\text { 生 成 }}{1 / R\left(=\mathrm{P}_{2} \mathrm{O}_{5} /\right.}$} & \multirow{2}{*}{$\begin{array}{c}\text { 条 } \\
\text { 妿获温 } \\
\text { 度 }\left({ }^{\circ} \mathrm{C}\right)\end{array}$} & \multirow{2}{*}{ 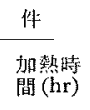 } & \multicolumn{3}{|c|}{$\begin{array}{c}\text { 酸性度 }(\mathrm{meq} / \mathrm{g})^{b)} \\
p K_{a}\end{array}$} \\
\hline & & & & $+\overline{1.5}$ & +3.3 & +6.8 \\
\hline 1 & 0.70 & 300 & 20 & 0.24 & 0.27 & 0.33 \\
\hline 2 & 1.00 & & & 0.24 & 0.25 & 0.34 \\
\hline 3 & 1.00 & & & 0.19 & 0.19 & 0.39 \\
\hline 4 & 1.00 & & & 0.15 & 0.30 & 0.39 \\
\hline 5 & 1.40 & & & 0.31 & 0.35 & 0.40 \\
\hline 6 & 2.00 & & & 0.24 & 0.61 & 0.74 \\
\hline 7 & 2.00 & & & 0.18 & 0.20 & 0.20 \\
\hline 8 & 2.20 & & & 0.57 & 0.62 & 0.71 \\
\hline 9 & 2.90 & & & 0.89 & 1.89 & 3.40 \\
\hline 10 & 3.00 & & & $\ldots \ldots, c)$ & $\ldots .$. & ...... \\
\hline 11 & 4.00 & & & $\ldots \ldots o$ & $\cdots \cdots$ & $\ldots \ldots$ \\
\hline 12 & 0.70 & 500 & 20 & 0.07 & 0.08 & 0.16 \\
\hline 13 & 1.00 & & & 0.05 & 0.17 & 0.19 \\
\hline 14 & 1.40 & & & 0.03 & 0.06 & 0.18 \\
\hline 15 & 2.00 & & & 0.13 & 0.16 & 0.67 \\
\hline 16 & 2.20 & & & 0.13 & 0.20 & 0.24 \\
\hline 17 & 2.90 & & & 1.37 & 2.11 & 2.32 \\
\hline 18 & 3.00 & & & 0.13 & 0.97 & 1.36 \\
\hline 19 & 4.00 & & & 0 & 5.09 & 6.67 \\
\hline 20 & 0.70 & 700 & 20 & 0.05 & 0.06 & 0.17 \\
\hline 21 & 1.00 & & & 0.02 & 0.02 & 0.07 \\
\hline 22 & 1.40 & & & 0.06 & 0.07 & 0.17 \\
\hline 23 & 2.00 & & & 0.08 & 0.10 & 0.10 \\
\hline 24 & 2.20 & & & 0.08 & 0.09 & 0.23 \\
\hline 25 & 2.90 & & & 0.06 & 0.06 & 0.16 \\
\hline 26 & 3.00 & & & 0.03 & 0.06 & 0.13 \\
\hline 27 & 4.00 & & & 0.26 & 0.31 & 1.45 \\
\hline 28 & 1.00 & 300 & 20 & 0.02 & 0.13 & 0.15 \\
\hline 29 & 2.00 & & & 1.99 & 2.19 & 2.29 \\
\hline 30 & 3.00 & & & 1.32 & 1.40 & 1.87 \\
\hline 31 & 4.00 & & & …... & $\ldots \ldots$ & $\ldots \ldots$ \\
\hline 32 & 1.00 & 500 & 20 & 0.08 & 0.08 & 0.08 \\
\hline 33 & 2.00 & & & 0.12 & 0.12 & 0.12 \\
\hline 34 & 3.00 & & & 0.72 & 0.92 & 1.12 \\
\hline 35 & 4.00 & & & 0.22 & 1.43 & 2.21 \\
\hline 36 & 1.00 & 700 & 20 & 0.20 & 0.20 & 0.30 \\
\hline 37 & 2.00 & & & 0.10 & 0.10 & 0.27 \\
\hline 38 & 3.00 & & & 0.10 & 0.13 & 0.21 \\
\hline 39 & 4.00 & & & 0.89 & 0.96 & 1.16 \\
\hline 40 & 1.00 & 300 & 20 & 0 & 0 & $0.0 \mathrm{I}$ \\
\hline $4 \mathrm{I}$ & 2.00 & & & 0.02 & 0.04 & 0.11 \\
\hline 42 & 3.00 & & & 0.63 & 0.70 & 0.83 \\
\hline 43 & 4.00 & & & 1.33 & 1.54 & 1.83 \\
\hline 44 & 1.00 & 500 & 20 & 0.01 & 0.15 & 0.16 \\
\hline 45 & 2.00 & & & 0.07 & 0.07 & 0.07 \\
\hline 46 & 3.00 & & & 0.08 & 0.12 & 0.13 \\
\hline 47 & 4.00 & & & 0.06 & 0.08 & 0.11 \\
\hline 48 & 1.00 & 700 & 20 & 0.12 & 0.12 & 0.15 \\
\hline 49 & 2.00 & & & 0.03 & 0.05 & 0.06 \\
\hline 50 & 3.00 & & & 0.08 & 0.08 & 0.08 \\
\hline 51 & 4.00 & & & 0.02 & 0.07 & 0.07 \\
\hline
\end{tabular}

注 $a$ ) No. 1 27： $\alpha-$ ルミナーリン酸二水絜フンモニウム系. No. 28〜39: $イ$ イルルナーリン酸三水素丁ンモニウム系。 No. 40 51: 水酸化子ルミニウムーリン酸二水沗フン王 二ウム录.

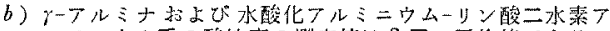
ソモニウム系の酸性度の湘定值柱 3 回の平均值で方吉。

c) 吸湿性のため测定不可能だ。た。
には四 9，10に示与ような相関関係が得られる。しかし3.1でも

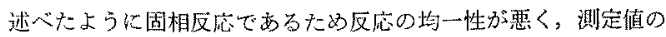
ばらつきは非常に大きい。

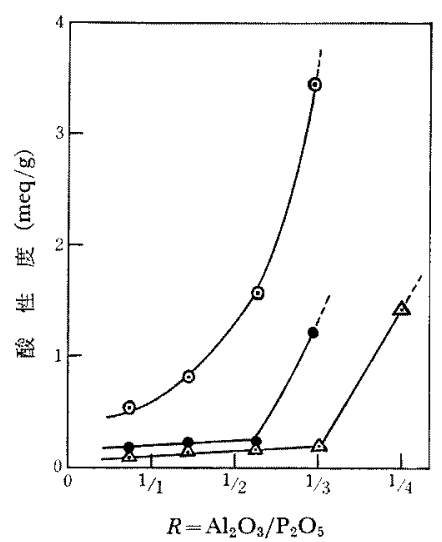

$\odot: 300^{\circ} \mathrm{G} \tau 20$ 時間加熱

๑: $500^{\circ} \mathrm{C}$ て 20 時間加熱

$\triangle: 700^{\circ} \mathrm{C}$ で 20 洔間加熱

酸性度は $\rho K_{a}=+6.8$ の捑である。

四 9 モル比 $(R)$ による酸性度の㽜化 $\left(\alpha-\mathrm{Al}_{2} \mathrm{O}_{8}-\mathrm{NH}_{4} \mathrm{H}_{2} \mathrm{PO}_{4}\right.$ 系)

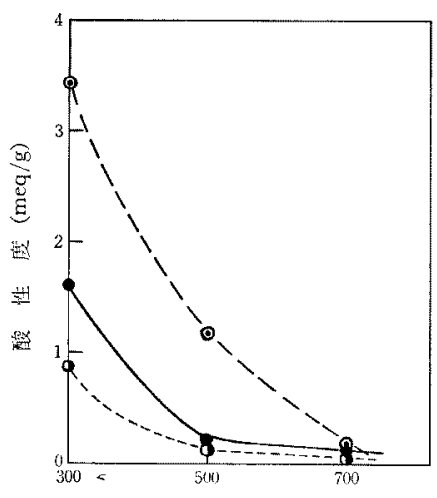

生成温度 $\left({ }^{\circ} \mathrm{C}\right)$

$\odot: R=1 / 2.9$

- : $R=1 / 2.2$

(): $R=1 / 1.4$

酸性愿は $p K_{a}=+6.8$ の值である。

図 10 生成温度による酸性度の变化 $\left(\alpha-\mathrm{Al}_{2} \mathrm{O}_{3}-\mathrm{NH}_{4} \mathrm{H}_{2} \mathrm{PO}_{4}\right.$ 系 $)$

麦 4 水洗儿上当酸性度の袈化

\begin{tabular}{|c|c|c|c|c|c|c|}
\hline 料 & 水 & 前 & $K_{a}$ & 水 & 後 & $K_{a}$ \\
\hline No. & +1.5 & +3.3 & +6.8 & +1.5 & +3.3 & +6.8 \\
\hline 29 & 1.99 & 2.19 & 2.29 & 0.13 & 0.11 & 0.14 \\
\hline 43 & 1.33 & 1.54 & 1.83 & 0.15 & 0.20 & 0.18 \\
\hline 52 & 1.80 & 2.07 & 2.35 & 0.05 & 0.13 & 0.17 \\
\hline 53 & 1.84 & 2.09 & 2.22 & 0.17 & 0.19 & 0.23 \\
\hline 54 & 1.61 & 1.62 & 1.90 & 0.03 & 0.09 & 0.09 \\
\hline 56 & 2.55 & 2.49 & 2.13 & 0.16 & 0.13 & 0.17 \\
\hline 57 & 1.41 & 1.46 & 1.39 & 0.11 & 0.11 & 0.10 \\
\hline
\end{tabular}


またリン酸系の場合とくらべてリン際二水素アンモ二ウム系

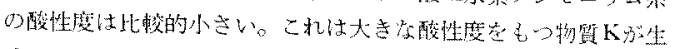
成し次いためであり，太物锤が生成しないのはアンモニアが残当 ためである。

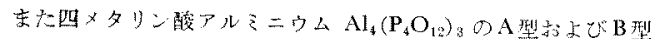

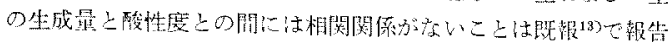

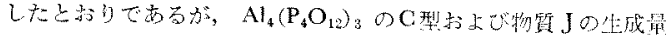

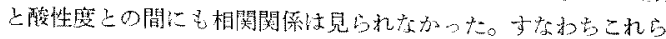

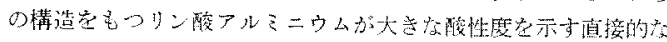
要因でない上考无られる。

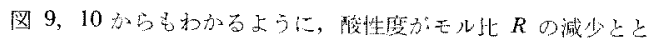

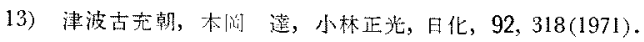

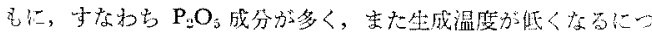

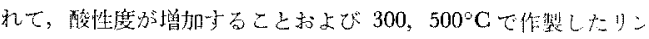
揹アルミニウムは $R=1 / 3 \sim 1 / 4$ 付近では吸湿性が夫きいこと, さらに表4からもかかるように，これらのリン酸アルミニウム艺

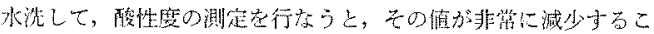
とから，无の固体酸の咥性発現の主なる要因はLewis酸によるも

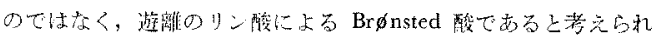
万o

終りに，本研究に古たり㮔々有益なご助言をいただきるした北 海道大学理学部田部浩三教授, 神拝女子莯科大学松尾恒婎教授,

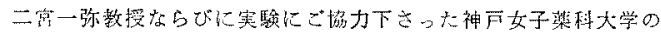

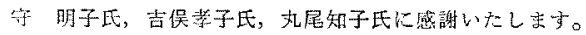
(1970 年 11 月, 日本薬学会近戨支部総会 (一部) 発表)

摩砕処理中の縮合リン酸塩によるメタクリル酸メチルのメカノケミカル重合*,*2

(昭租 46 年 8 月 23 日受理)

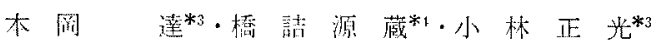

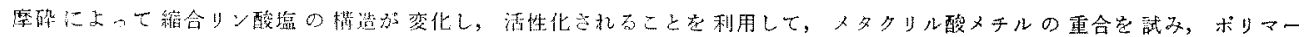

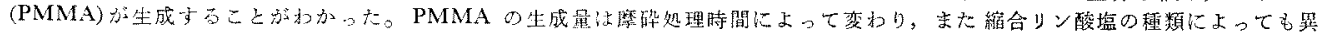

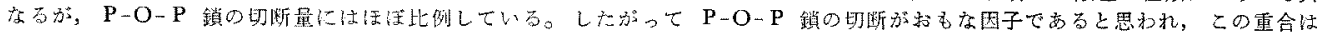

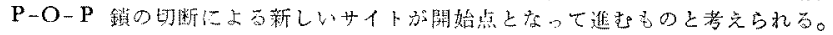

\section{1 緒言}

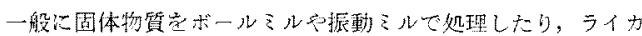
イ(擂潰)機で糜砕したりすると表面がいらじるしく活性になるこ

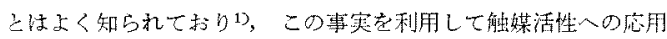
もなされている。たと充ば，Ziegler-Natta 触媒を层動ボールミ

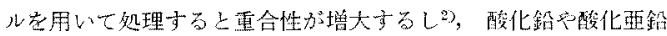

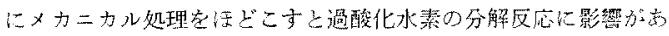

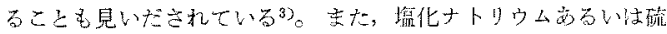
酸ナトリウム交どの無機化合物を高分子モノマーといっしょにメ

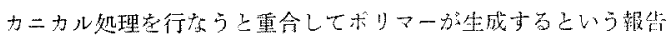
无る゙。

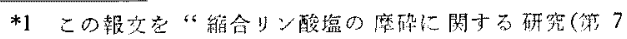
報)”と方。

*2 前報(第 6 報)， I. Motooka， G. Hashizume, M. Kobayashi, J. Phys. Chem., 73, 3012(1969).

*3 Itaru MotookA, Masamitsu KoBAYAsHI 神亞大管数

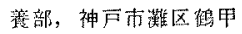

*4 Genzo HASHIZUME 兵庫鼠工浆武蜸場，神户市須磨区 行平时

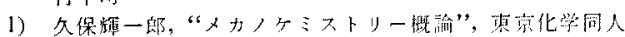
(1971)；傅.

2) T. Keii, T. Akiyama, Nature, 203, 76(1964); 他.

3) G. L. Clark, R. Rowan, J. Amer. Chom. Soc., 63,

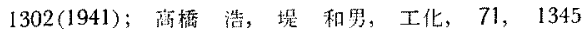
(1968).

4) N. K. Baramboim, Zh. Fiz. Khim., 32, 432(1958); N. A. Plate, V. A. Kargin, J. Polym. Sci., C, 4, 1027 (1963).
著者らは摩研によって縮合りン酸㯰の P-O-P 艋の切断が起

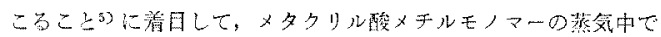

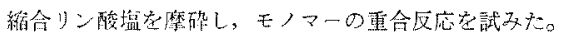

\section{2 実}

\section{1 試 料}

リン酸篮: 用いだン酸壦は $\mathrm{NaH}_{2} \mathrm{PO}_{4}, \mathrm{Na}_{2} \mathrm{H}_{2} \mathrm{P}_{2} \mathrm{O}_{7}, \mathrm{Na}_{4} \mathrm{P}_{3} \mathrm{O}_{7}$, $\mathrm{Na}_{3} \mathrm{P}_{3} \mathrm{O}_{3}, \mathrm{NaPO}_{3} \mathrm{G}$ (Graham 塩), $\mathrm{NaPO}_{3} \mathrm{M}$ (Maddrel 程 II 型), $\mathrm{KPO}_{3}$ (Kurrol 增), $\mathrm{LiPO}_{3}$ (I 型)で, 既報》の上うにしてつくっ $7=0$

高分子モノマー:メタタリル酸メテル(MMA)は和光純薬の特 級品导用いた。

\section{2 方 法}

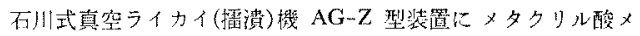

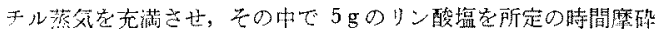

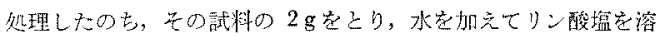

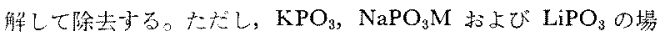

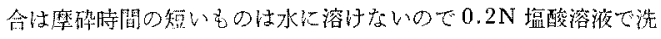

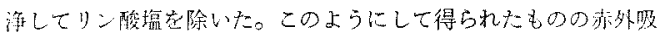

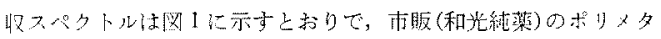

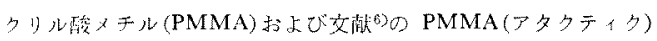

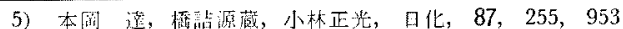
(1966); 1. Motooka, G. Hashizume, M. Kobayashi, Bull. Chem. Soc. Jap., 40, 2095(1967); 41, 2040(1968);

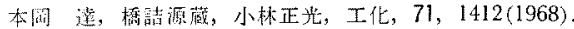

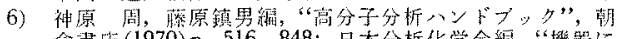

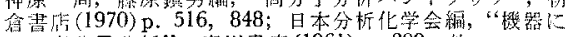

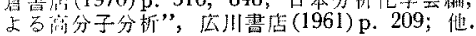

